\title{
MANAJEMEN KEHUMASAN DI PERGURUAN TINGGI
}

\author{
Oleh \\ Lena Satlita \\ FISE UNY
}

\section{Abstrak}

Otonomi pendidikan tinggi, perkembangan teknologi informasi dan komunikasi, meningkatnya kompetisi antar perguruan tinggi di dalam maupun luar negeri, berkembangnya media massa cetak dan eletronik, kristisnya pandangan masyarakat terhadap perkembangan pendidikan tinggi dan kebijakan-kebijakan pemerintah pusat dan daerah yang terkait dengan masyarakat, pendidikan dan perguruan tinggi, menyebabkan perguruan tinggi harus 'mengkemas' informasi yang di sampaikan pada publik agar publik dapat memperoleh pemahaman yang jelas dan mendukung berbagai kebijakan dan produk yang dirasilkan suatu perguruan tinggi.

Manajemen kehumasan perguruan tinggi harus didasarkan pada pemahaman yang tepat terhadap persoalan kehumasan yang dihadapi oleh sebuah perguruan tinggi. Oleh karenanya proses rencana program kerja humas yang efektif pada dasarnya adalah sebuah proses yang diawali dengan penentuan masalah melalui penelitian, perencanaan, pelaksanaan sampai dengan evaluasi. Dengan demikian dapat dihasilkan suatu program kerja kehumasan yang tidak saja sejalan dengan visi dan misi perguruan tinggi tetapi juga misi pckok Humas perguruan tinggi yaitu membangun image positif, menumbuhkan komunikasi yang sinergis antara perguruan tinggi dengan masyarakat dan membangun institusi yang responsif terhadap dinamika masyarakat.

Kata kunci: manajemen, kehumasan, perguruan tinggi

\section{Pendahuluan}

Era globalisasi yang bercirikan persaingan ketat merupakan tantangan besar yang harus dihadapi berbagai negara khususnya negara yang sedang berkembang, tidak terkecuali Indonesia. Dalam era global terjadi berbagai bentuk perubahan pada aspek kehidupan yang disebabkan karena perkembangan teknologi informasi yang luar biasa cepat dan arus dan interaksi informasi yang tidak dapat dikendalikan oleh kekuatan manapun. Keterbukaan dalam berbagai sistem kehidupan secara terus merierus akan menjadi 
wacana dan cita-cita yang penting bagi kehidupan miasyarakat. Menurut Zulkarnain Nasution (2006), perubahan-perubahan yang terjadi pada era global tidak terkecuali akan berimbas pada bidang/lembaga pendidikan (termasuk perguruan tinggi) yang merupakan lembaga mengemban amanat ilmu pengetahuan. Perkembangan ilmu pengetahuluan dan teknologi yang pesat akan membawa konsekuensi program pendidikan juga harus mampu mengikutinya dalam konteks kekinian dan masa mendatang. Perubahan yang terjadi juga akan membawa dampak pada cepat usangnya kebijakan maupun prakarsa pendidikan. Begitu pula parameter kualitas pendidikan, akan berubah secara cepat dari waktu ke waktu.

Sejalan dengan dilancarkannya reformasi dalam tatanan politik dan sistem kenegaraan di Indonesia, sistem pendidikan tinggi mendapatkan momentum untuk melaksanakan otonomi yang telah lama diharapkan. Adanya keinginan untuk memberdayakan dan menyelamatkan perguruan tinggi negeri (PTN) dari ketidak berdayaan sistem pendidikan dan birokrasi kenegaraan menuju otonomi pendidikan, melahirkan Peraturan $\mathrm{Pe}-$ merintah No. 61 Tahun 1999 tentang Penetapan Perguruan Tinggi Negeri sebagai Badan Hiukum. Target agar tahun 2010 semua PTN beralih status menjadi BHMiv menimbulkan opini publik pro dan kontra baik dikalangan publik intern perguruan tinggi (dosen, mahasiswa dan karyawan) maupun publik ekstern (orang tua dosen dan masyarakat luas). Opini publik yang berkembang di masyarakat yang kontra karena pemahaman yang keliru terhadap konsep PT BHMN. Menurut Nasution (2006:75), kekeliruan tersebut antara lain: $B H M N$ identik dengan swastanisasi, BHMN dimaknai sama dengan BUMN, terjadinya kapitalisasi PTN, terjadinya komersialisasi pendidikan, terjadinya pelepasan tanggungjawab negara atau pemerintah terhadap pembiayaan pendidikan tinggi dan pendanaan sepenuhnya ditanggung sepenuhnya oleh universitas. Opini yang keliru ini menyebabkan kebijakan PT BHMN sampai saat ini masih mendapat tantangan dari berbagai pihak, terutama mahasiswa yang langsung terkena dengan kebijakan tersebut. Berbagai demo menentang kebijakan tersebut masih kerap terjadi dan merupakan tantangan bagi perguruan tinggi untuk meluruskan opini publik yang kontra menjadi opini yang pro, dalam pengertian masyarakat dapat memahami PT BHMN secara jelas dan benar.

Uraian di atas menunjukkan bahwa saat ini dan ke depan tidak mudah lagi untuk berkomunikasi dengan masyarakat yang semakin kritis. Fungsi komunikasi tidak lagi dapat dilakukan sambil lalu atau dirangkap oleh fungsi lain, tetapi 
harus dijalankan oleh suatu bagian khusus yang menangani komunikasi ke luar maupun ke dalam, yang sering disebut dengan hubungan masyarakat (humas) atau public relations (PR). Humas (PR) adalah suatu pendekatan strategis yang menggunakan konsep-konsep komunikasi untuk menimbulkan pemahaman dan penerimaan dari publik. Sebagai alat manajemen, humas pada suatu lembaga pendidikan kini tak terelakkan lagi. Tulisan berikut ini akan menguraikan tentang manajemen komunikasi kehumasan di perguruan tinggi.

\section{Konsep Dasar Hubungan Masya- rakat/Public Relations}

Grunig dan Hunt mendefinisikan kegiatan humas sebagai kegiatan komurikasi, "the management of communication between an organization and its public (Baskin, Aronoff dan Lattimore, 1997:5). Marston ((1979) mendefinisikan "public relations is planned, persuasive communication designed to influence significant public". Menurut Harlow, humas merupakan komunikasi dua arah antara organisasi dengan publik secara timba! balik dalam rangka mendukung fungsi dari tujuan manajemen dengan meningkatkan pembinaan kerjasama serta pemenuhan kepentingan bersama (Ruslan, 1999:102). Definisi-definisi tersebut menjelaskan bahwa humas merupakan kegiatan komunikasi yang dilakukan sebuah organisasi dengan berbagai publiknya.
Domain kegiatan humas adalah komunikasi dalam bentuk komunikasi dua arah. Di satu sisi, organisasi melakukan penyebaran informasi kepada publik. Di sisi lain organisasi juga melakukan pencarian informasi, mendengarkan apa yang menjadi keinginan publik organisasi.

Definisi lain mengkonsepsikan humas lebih dari sekedar kegiatan komunikasi. Humas adalah sebuah fungsi manajemen yang berkaitan dengan usaha untuk membangun hubungan yang saling menguntungkan (mutually beneficial relationship) antara sebuah organisasi dengan publiknya, seperti yang dinyatakan oleh Cutlip, Center dan Broom (1994:6), " the management function that establishes and maintains mutually beneficial relationship between an organization and the publics on whom its success or failure depend". Cutlip dkk melihat humas sebagai fungsi manajemen untuk membangun dan menjaga hubungan yang saling menguntungkan antara organisasi dan publiknya yang menentukan keberhasilan atau kegagalan organisasi tersebut. institute of Public Relations (IPR) seperti dikutip Anggoro (2001:2) menjelaskan humas sebagai " keseluruhan upaya yang dilangsungkan secara terencana dan berkesinambungan dalam rangka menciptakan dan memelihara niat baik dan saling penger- 
tian antara suatu organisasi dengan segenap khalayaknya".

Menurut Ngurah (1999) keti-ka organisasi berbicara relations with public, maka harus dipahami bahwa masing-masing pihak yang sedang membangun hubungan memiliki kepentingan. Organisasi memiliki kepentingan, begitu juga dengan publik dan hubungan kedua belah pihak akan berjalan harmonis bila masing-masing dapat saling mempertimbangkan kepentingan pihak lain. Karena organisasi diasumsikan beroperasi lantaran diberi hak oleh publik dan bahwa hak itu tidak bisa dihindari, manajemen setiap organisasi memiliki kewajiban memberikan layanan kepada publik dengan sebaik-baiknya.

Sejalan dengan definisinya, maka secara konseptual dan metodologis, fungsi humas adalah sama di semua organisasi, yakni berupaya membina hubungan harmonis melalui sistem saluran komunikasi dua arah dengan publik agar tercapai opini dan persepsi yang positif, dan untuk memperoleh citra organisasi yang baik . Edwin dan Emery (1988:32) menegaskan fungsi humas adalah menciptakan hubungan-hubungan yang saling bermanfaat antara sebuah lembaga dengan berbagai publiknya yang diupayakan secara terencana dan terorganisasi. Howard Childs (Ngurah, 1999:5), menyebutkan fungsi dasar humas bukan untuk menampilkan pandangan organisasi atau seni sikap publik, tetapi untuk mela- kukan rekonsiliasi atau penyesuaian terhadap kepentingan publik setiap aspek pribadi organisasi maupun perilaku perusahaan yang punya signifikan sosial.

Konsep tersebut punya konsekuensi penting, karena penyesuaian organisasi mengisyaratkan sebuah fungsi yang berada pada level manajemen organisasi. Konsep ini menekankan pentingnya tindakan-tindakan perbaikan yang harus dilakukan organisasi di samping usaha-usaha untuk berkomunikasi. Humas sebagai fungsi manajemen berkaitan dengan bagaimana sebuah organisasi menyusun kebijakan sehingga memperlihatkan sebuah kinerja yang bertanggungjawab. Ini berkaitan dengan Kenyataan bahwa penampilan yang bertanggungjawab merupakan dasar penerimaan publik terhadap sebuah organisasi. Hal ini berarti, humas sebuah organisasi tidak sematamata menjadi tanggungjawab praktisi humas tetapi harus menjadi tanggungjawab para pengelola organisasi tersebut.

\section{Manajemen Kehumasan Perguru- an Tinggi}

Seperti telah diuraikan di atas, fungsi sentral public relations adalah menunjang manajemen dalam mencapai tujuan organisasi, dengan komunikasi sebagai kegiatannya yang utama. Sasaran kegiatan public relations adalah publik 
intern dan ekstern, sedangkan tujuannya adalah terbinanya hubungan harmonis antara organisasi/lembaga yang diwakilinya de-ngan publiknya atau stakeholders sasaran khalayak yang terkait - pada akhir tujuannya: diharapkan akan tercipta citra positif (good image), kemauan yang baik (good will), saling menghargai (mutual ap-preciation), saling timbul pengertian (mutual understanding), toleransi (tolerance) antara kedua belah pihak yang terkait dan sebagainya. Dengan demikian, perguruan tinggi yang unggul adalah perguruan tinggi yang mampu mengelola hubungan dengan stakeholder nya yang meliputi maha-iswa, dosen, staf administrasi, alumni, masyarakat, pemerintah, media pers, orang tua mahasiswa, dll, sehingga melalui hubungan yang baik dan strategis itu dapat mencapai tujuan perguruan tinggi secara realistis. Humas perguruan tinggi dituntut untuk mampu membangun image positif terhadap lembaga dalam memasuki era ke depan (globalisasi, era otonomi pendidikan), menumbuhkar. komunikasi yang sinergis antara lembaga pendidikan dengan masyarakat dan membangun institusi responsif terhadap dinamika masyarakat. Dengan demikian fungsi humas perguruan tinggi dituntut selalu profesional dalam mengelola informasi sehingga terwujudnya citra positif lembaga. Tuntutan ini mensyaratkan perlunya manajemen terhadap pengelolaan komunikasi (humas) di perguruan tinggi.

$$
\text { Menurut Ngurah }
$$
kegiatan komunikasi yang diadakan oleh organisasi memang seharusnya dikelola dengan baik. Tanpa manajemen terhadap kegiatankegiatan ini, organisasi tidak dapat mengetahui sumbangan apa yang diberikan kegiatan kehumasan terhadap organisasi. Dalam praktek keorganisasian, sangat sering terjadi kegiatan kehumasan yang dilakukan tidak terkelola dengan baik. Biasanya kegiatan kehumasan dilakukan tanpa perencanaan, tanpa evaluasi, walaupun ada pelaksanaan kegiatan. Ngurah mengatakan bahwa pada dasarnya manajemen humas dapat diartikan sebagai penerapan konsep-konsep manajemen ke dalam kegiatan humas mulai dari merencanakan suatu program kerja humas, mengorganisasikannya, melaksanakannya hingga mengevaluasi suatu program kerja humas. Program kerja humas yang baik harus didasarkan pada pemahaman yang tepat terhadap persoalan kehumasan yang dihadapi oleh sebuah organisasi. Oleh karenanya kegiatan humas yang efektif pada dasarnya adalah sebuah proses yang diawali dengan penentuan masalah melalui penelitian.

Scott M.Cutlip \& Allen H.Center (1982:139), mengatakan sebagai landasan acuan untuk 
pelaksanaan program kerja humas dapat dilakukan melalui "proses empat tahapan atau langkah-langkah pokok" yaitu:

\section{Reseacrh - Penemuan fakta (Fact Finding)}

Pada tahap ini, akan ditetapkan suatu fakta dan informasi yang berkaitan langsung dengan kepentingan organisasi. Penemuan fakta dilakukan untuk mengetahui apakah opini, sikap dan reaksi (situasi dan pendapat) dalam masyarakat menunjang atau justru menghambat organisasi, instansi atau perusahaan ( what's our problem?). Dalam tahap penemuan fakta ini seorang petugas humas dituntut:

1. Memperhatikan berbagai kejadian atau perkembangan sosial, politik maupun ekonomi yang secara langsung atau tidak langsung berhubungan dengan lembaga atau perusahaan

2. Mengumpulkan berbagai macam data untuk diolah menjadi infomasi

3. Menganalisis infomasi itu agar sesuai dengan keperluan lembaga atau perusahaan

4. Selalu siap menyajikan berbagai informasi secukupnya kepada setiap unit organisasi atau perusahaannya.
5. Menyempurnakan segala ma-cam informasi yang dirasakan masih kurang memadai.

6. Melengkapi simpanan data dan informasi antara lain de-ngan menyelenggarakan dokumentasi dan press clipping

Sehubungan dengan kegiatan penemuan fakta ini, khususnya yang menyangkut opinion research, maka Cutlip dan Center menemukan empat tahap penelitian yaitu:

1. penelitian tentang situasi yang sedang terjadi (current situation), khususnya mengenai apa yang sedang dipikirkan orang dan mengapa.

2. Penelitian tentang prinsipprinsip dasar humas yang sedang dilaksanakan oleh organisasi atau perusahaan.

3. Penelitian tentang hasil, bagaimana orang memberikan reaksi terhadap protesting yang diadakan oleh organisasi atau perusahaan, misalnya terhadap reaksi pendapat atas suatu iklan ataupun artikel khusus yang ditulis oleh bagian humas. 
4. Mengadakan evaluasi mengenai bagaimana orang memberikan reaksi dan responnya terhadap stimuli lainnya yang diberikan oleh organisasi ataupun perusahaan.

Porencanaan dan Mengambil Koputusan (Planning - Decision)

Perencanaan merupakan tahap yang cukup penting, karena menghubungkan kegiatan komunikasi dengan kepentingan organisasi/perusahaan. Dalam tahap ini yang merupakan kelanjutan dari tahap fact finding - atas dasar hasil penelitiannya, seorang petugas humas merencanakan bagaimana sebaiknya dengan memperhatikan faktor-faktor psikologis, sosiologis, keadaan sosial, ekonorni politik pesan dari komunikator dirumuskan agar dapat mencapai tujuannya.

Berdasarkan hasil fact finding, dalam tahap ini sejumlah langkah yang perlu dilakukan, yaitu

1. Merumuskan apa tujuan yang harus dicapai oleh humas ketika mengirim pesan tertentu.

2. Mengolah data yang diperolehnya tentang berbagai faktor yang diperlukan

3. Merumuskan bagaimana pesan harus disebarkan

4. Menentukan teknik komunikasinya

5. Memeriksa kesempurnaan informasi yang diperolehnya pada tahap fact finding
6. Membandingkan pengalaman-pengalaman pihak lain dan organisasinya sendiri guna memperoleh langkah terbaik

7. Mengadakan analisis atas informasi yang diperoleh serta merumuskannya sesuai dengan program kerja, yaitu sesuai dengan situasi dan tempat.

Komunikasi - Pelaksanaan (Communication - Action)

Tahapan komunikasi tidak terlepas dari perencanaan tentang bagaimana mengkomunikasikan dan apa yang dikomunikasikan sehingga menimbulkan kesan-kesan yang secara efektif mempengaruhi pihak-pihak yang dianggap penting dan berpotensi dalam upaya memberikan dukungan sepenuhnya. Bagaimana mengkomunikasikan sesuatu dan apa yang dikomunikasikan, sebenarnya tidak terlepas dari tujuan yang hendak dicapai melalui kegiatan kehumasan. Suatu program komunikasi menyangkut pilihan-pilihan terhadap saluran komunikasi yang akan digunakan dalam berkomunikasi dengan publik sasaran. Untuk itu, pilihan media atau saluran komunikasi tergantung pada publik sasaran. Pilihan media saluran dipengaruhi oleh antara lain faktor ketersediaan media, biaya, ketrampilan komunikasi, publik sasaran dan tujuan komunikasi. 
Selain pilihan media/ saluran komunikasi, dalam program komunikasi, perlu juga ditentukan jenis pesan dan tema-tema yang harus ditonjolkan. Selain itu menurut Ngurah (1999), implementasi program kehumasan dilakukan tidak hanya dengan program komunikasi, tetapi juga program tindakan untuk menyelesaikan masalah yang dihadapi organisasi Kedua cara tersebut perlu dilakukan karena masalah hubungan perusahaan dengan publik tidak saja disebabkan kesalahan berkomunikasi tetapi juga faktor-faktor non komunikasi (kesalahan berperilaku, membuat kebijakan, dII) Karena masalah kehumasan bisa disebabkan faktor komunikasi dan non komunikasi, maka Humas perlu mengusulkan program tindakan untuk menunjang penyelesaian masalah. Sebagai contoh untuk melakukan sebuah program kampanye kebersihan, program tindakan (menunjang) yang perlu dilakukan adalah antara lain penyediaan tong sampah ditempat umum dan pengangkutan sampah.

\section{Evaluasi (Evaluation).}

Setelah komunikasi dilaksanakan, maka sesuatu organisasi tentu ingin mengetahui dampak atau pengaruhnya terhadap publik atau khalayak. Pada tahapan ini humas mengadakan penilaian terhadap hasilhasil dari program-program kerja atau aktivitas humas lainnya yang telah dilaksanakan, serta keefektivitasan dari teknik-teknik manajemen, dan komunikasi yang telah dipergunakan. Menurut Ngùrah (1999) evaluasi program humas penting dilakukan karena

1. Dengan menunjukkan nilai program kehumasan bagi perusahaan, maka manajer humas dapat mempertahankan program-program tersebut dan keberadaan bagian Humas.

2. Tuntutan dari setiap manajemen perusahaan terhadap setiap bagian diperusahaan agar setiap pengeluaran sumber daya dapat dipertanggungjawabkan.

3. Pemikiran/pendapat kalau program/ bagian humas merupakan bagian yang menghamburham-burkan uang (biaya besar, tidak jelas hasil pencapaian objektif tertentu)

4. Bagian dari usaha untuk peningkatan status profesionalisme para praktisi humas.

Sedangkan menurut Kendall (1992), evaluasi dapat dilakukan melalui tujuh kategori untuk mengetahui program humas berhasil/efektif yaitu: :

1. Pencapaian sasaran (goal achievement), sejauh mana tujuan-tujuan yang telah ditetapkan dapat tercapai.

2. Pengukuran perbaikan (measurement of improvement), apakah situasi sudah menga- 
lami perbaikan (sikap/pengetahuan publik).

3. Pengukuran hasil (measure-ment of result), yaitu Evaluasi pada apa yang sudah dibuat/dihasilkan humas, tapi belum pada pencapaian tujuan yang tetap.

4. Efisiensi biaya (cost efficien-cy), yaitu mengukur sukses program humas dengan menghitung nilai uang yang dihasilkan program humas dengan usaha-usaha atau jumlah uang yang dikeluarkan (cost-benefit analysis, membandingkan nilai yang diperoleh dengan sumber daya yang dihabiskan)

5. Perubahan organisasi (organizational change), yaitu evaluasi terhadap program humas apakah berpengaruh pada perubahan dalam organisasi (misal : meningkatkan semangat kerja karyawan).

6. Efek yang tak terencana (unplanned effect), untuk mengetahui apakah ada hasil-hasil sampingan yang justru muncul sebagai akibat dari program humas. (misal : karyawan jadi komipak,dII).

7. Harapan-harapan tak terakulasi (unarticulated hopes), yaitu evaluasi terhadap harapan-harapan pihak manajemen yang tidak terakulasi dengan baik. Setiap tujuan program harusnya sudah teridentifikasi dengan jelas se- luruh harapan-harapan yang dimiliki oleh pihak manajemen.

Grunig \& Hunt (dalam Ngurah, 1999) tahap-tahap yang perlu dilaku-kan untuk mengevaluasi :

1. Buat rumusan tujuan program yang spesifik dan dapat diukur (specity objectives).

2. Pengukuran efek yang sudah dicapai dari program yang dijalankan (measures the objectives).

3. Pengumpulan data dan mengukur efek pada sample terpilih.

4. Buat laporan tentang hasil program kepada pengambil keputusan (manajemen). Setiap hasil program harus diterapkan pada pengambilan keputusan (hasil yang dicapai untuk memperbaiki program selanjutnya

Menurut Ruslan (2002:142), setiap tahap dari proses kerja humas di atas, sama pentingnya bagi ter-laksananya suatu program humas yang efektif, saling berhubungan erat dan tidak dapat dipisahkan. Proses kerja humas merupakan satu kesatuan yang secara sirkuler terus-menerus berlangsung. Proses analisis-sintesis-komunikasi-interpretasi dari kerja humas merupakan proses yang berkesinambungan dalam bentuk spiral dan seringkali tumpang tiridih antara satu dengan lainnya. Kálau diuraikan dan digambarkan maka lingkaran dan langkah-langkah ke- 
giatan humas adalah sebagai berikut:

1. Menganalisis perilaku umum dan hubungan organisasi terhadap lingkungan

2. Menentukan dan memahami secara benar perilaku tiap-tiap kelompok terhadap organisasi.

3. Menganalisis tingkat opini publik, baik yang intern maupun yang ekstern.

4. Mengantisipasi kecenderungan-kecenderungan, masalah-masalah yang potensial, kebutuhan-kebutuhan dan kesempatan-kesempatan.

5. Menentukan formulasi dan merumuskan kebijakan-kebijakan
6. Merencanakan alat atau cara yang sesuai untuk meningkatkan atau mengubah perilaku kelompok masyarakat sasaran

7. Menjalankan dan melaksanakan aktivitas-aktivitas sesuai dengan program yang telah direncanakan

8. Menerima umpan balik untuk dievaluasi, kemudian mengadakan penyesuaianpenyesuaian yang diperlukan.

Bila langkah-langkah tersebut digambarkan, menurut Ruslan (2002: 145) akan tampak sebagai berikut: 


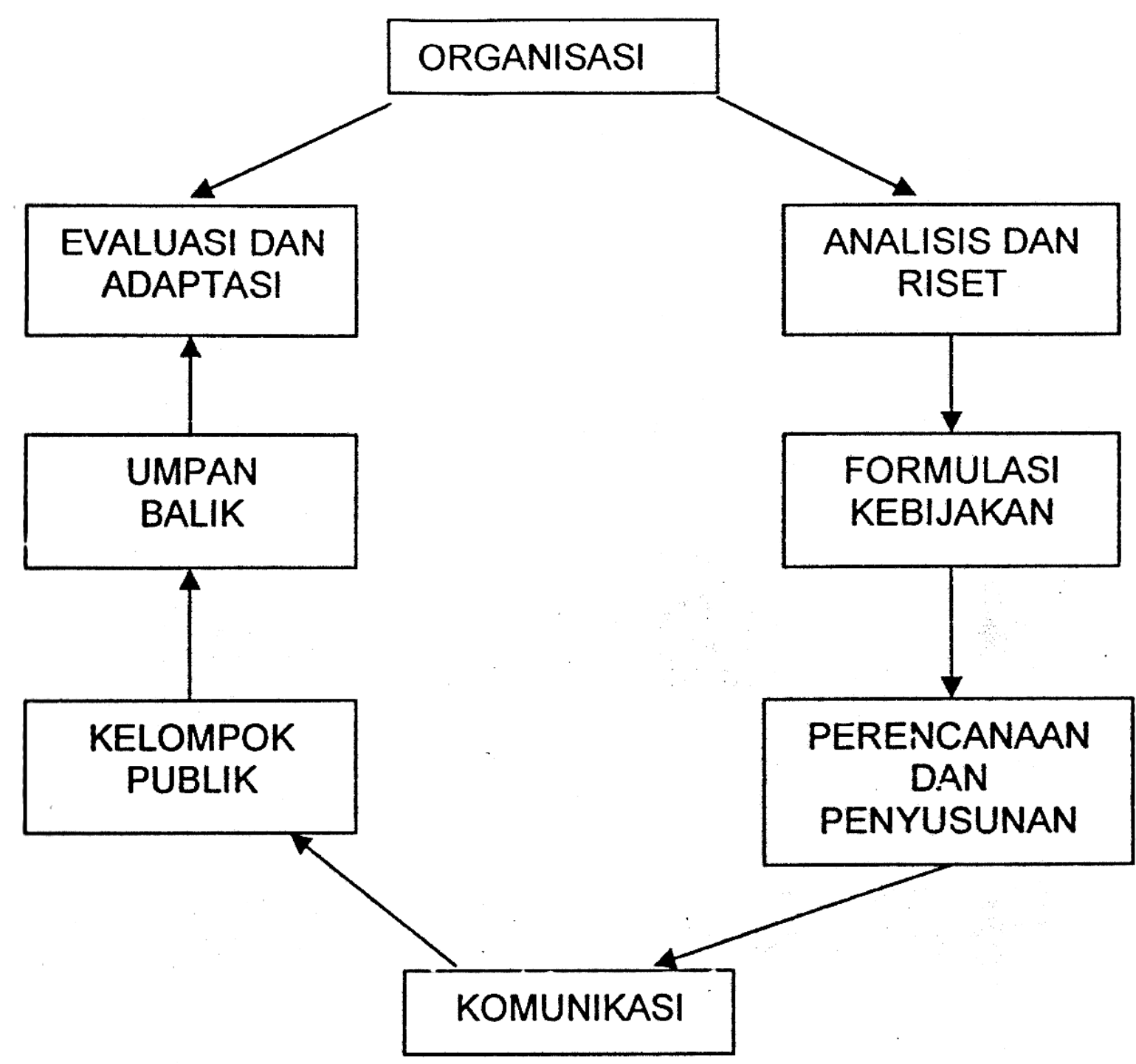

Gambar 1. Langkah-langkah proses kerja humas

Untuk membuat program kerja humas yang efektif bukanlah merupakan pekerjaan yang mudah, karena publik yang menjadi sasaran amat kompleks dan manajemen organisasi yang harus didukung juga rumit. Oleh karenanya keberhasilan manajemen humas sangat tergantung pada posisi/kedudukan serta kemampuan praktisi Humas. Ruslan (2002) mengatakan agar Humas perguruan tinggi dapat melaksanakan fungsi strategis maka harus diupayakan :

1. Menempatkan posisi Humas dekat dengan pimpinan lembaga pendidikan agar humas mengetahui secara jelas dan rinci mengenai pola perencanaan, kebijakan, keputusan yang diambil, visi dan arah tujuan lembaga pendidikan ybs, agar tidak terjadi 
kesalahan dalam penyampaian pesan dan onformasi yang bersal dari lembaga pendidikan ke pada masyarakat.

2. Humas dalam memberikan informasi mewakili lembaga pendidikan tersebut dapat dipertegas tentang batas-batas wewenang dan tanggung-jawab dalam memberikan keterangan (sebagai juru bicara). Dengan demikian humas akan selalu mengetahui informasi secara jelas mengenai pelaksanaan dari keputusan atau kebijaksanaan pimpinan lembaga pendidikan tersebut.

3. Pimpinan atau staf humas selalu diikutsertakan menghadiri setiap rapat atau periemuan pada tingkat pimpinan agar dapat mengetahui secra langsung dengan tepat tentang "latar belakang" suatu proses perencanaan, kebijaksanaan, arah dan tujuan organisasi yang hendak dicapai, baik dalam jangka pendek maupun panjang.

4. Humas diberi fungsi koordinasi berhubungan secara langsung dan segera dengan pimpinan puncak (Rektor/Direktur) tanpa melalui perantara pejabat/bagian lain sehingga fungsi kehuma-san berlangsung secara optimal, antisipatif dan dapat melaksanakan berbagai macam perencanaan, peranan komunikasi. Atau dengan kewenangan yang ada mampu mengatasi berbagai masalah yang mungkin akan timbul tanpa diduga sebelumnya.

5. Humas harus bertindak secara proaktif dan dinamis, serta fleksibel sebagai nara sumber atau mengatur saluran komun ikasi baik ke dalam maupun ke luar untuk menghindarkan sikap reaktif (pasif) dalam menghadapi berbagai masalah atau tantangan yang bakal dihadapinya.

6. Humas berperan melakukan tindakan mulai dari memonitor, merekam, menganalisi, merielaah hingga mengevaluasi setiap reaksi feed back, khususnya dalam upaya penilaian sikap tindak serta mengetahui persepsi masyarakat sebagai suatu akibat yang ditimbulkan dari keputusan yang diambil dan kebijakan telah dijalankan oleh pihak lembaga pendidika!n

7. Humas dapat miemberikan sumbangsaran, ide, dan rencana atau program kerja kehumasan untuk memperbaiki atau mempertahankan nama baik, kepercayaan, 
dan citra organisasi terhadap publiknya., termasuk menjembatani atau menyerasikan antara kebijaksanaan/keputusan pimpinan lembaga pendidikan dengan kepentingan /keinginan masyarakat sekaligus memperoleh dukungan dan partisipasi dari masyarakat.

\section{Ponutup}

Berbagai perubahan yang terjadi akibat globalisasi dan reformasi yang berimbas pada dunia/ lembaga pendidikan menyebabkan perguruan linggi harus menata komunikasinya ko publik internal maupun eksternal. Konsekuensi dari hal tersebut, perlu ada suatu bagian yang bertugas untuk mengelola komunikasi dan informasi yang di sampaikan pada publik agar publik dapat memperoleh pemahaman yang jelas dan mendukung berbagai kebijakan dan produk yang dihasilkan suatu perguruan linggi. Fungsi dan peran Humas perguruan tinggi selaku sumber informabl perlu diberdayakan baik menyangkut SDM nya maupun posisi nya dalam struktur organisasi. Pencapaian lujuan dan sasaran humas akan dapat diwujudkan jika aktivitas humas lororganisasi dengan baik melalui manajemen humas yang dikelola secara professional.

Melalui manajemen kehumasan, dapat dibuat suatu program kerja humas yang tepat sasaran karena didasarkan pada pemahaman yang jelas terhadap persoalan kehumasan yang dihadapi oleh sebuah organisasi. Sehingga misi pokok Humas perguruan tinggi untuk membangun image positif, menumbuhkan komunikasi yang sinergis antara perguruan tinggi dengan masyarakat dan membangun institusi yang responsif terhadap dinamika masyarakat dapat terwujud.

\section{Daftar Pustaka}

Basikin, O., \& Aronof, C. 1997. Public Relations:The Profession and the Practice. Edisi Keempat, Madison,WI: Brown \& Bench-mark.

Cutlip, S.M.,Center,A.H. \& Broom, G.M. 1994. Effective Public Relations. Edisi keenam. New Jersey: Prentice Hall.

Grunig, J.E. 1992. Excellence in Public Relations and Communication Management. New Jer-sey, Lawrence Erlbaum Associate, Inc.

I Gusti Ngurah Putra. 1999. Manajemen Hubungan Masyarakat. Yogyakarta: Penerbit UAJ.

Jefkins, Frank. 1996. Public Relations (terjemahan). Jakarta: penerbit Erlangga

Rosady Ruslan.2002. Manajemen Humas dan Manajemen Komunikasi. Jakarta: PT Raja Grafin-do Persada. 
Zulkarnain Nasution. 2006. Manajemen Humas di Lembaga Pendidikan. Malang: UMM Press.

\section{Biodata Penulis}

Lena Satlita, dosen tetap pada Jurusan Administrasi, prodi Administrasi Perkantoran FISE UNY. Menamatkan $S$ 1, jur. Administrasi Negara dan S2. jur. IImu Politik di UGM. 